\title{
BMJ Open Currently prescribed drugs in the UK that could upregulate or downregulate ACE2 in COVID-19 disease: a systematic review
}

\author{
Hajira Dambha-Miller (D) , ${ }^{1,2}$ Ali Albasri (D) , ${ }^{3}$ Sam Hodgson (D) , ${ }^{1}$ \\ Christopher R Wilcox, ${ }^{1}$ Shareen Khan, ${ }^{4}$ Nazrul Islam (D) , ${ }^{2,5}$ Paul Little (D) , ${ }^{1}$ \\ Simon J Griffin ${ }^{2}$
}

To cite: Dambha-Miller H, Albasri A, Hodgson S, et al. Currently prescribed drugs in the UK that could upregulate or downregulate ACE2 in COVID-19 disease: a systematic review. BMJ Open 2020;10:e040644. doi:10.1136/ bmjopen-2020-040644

- Prepublication history for this paper is available online. To view these files, please visit the journal online (http://dx.doi. org/10.1136/bmjopen-2020040644).

Received 19 May 2020 Revised 02 July 2020 Accepted 04 August 2020
Check for updates

(C) Author(s) (or their employer(s)) 2020. Re-use permitted under CC BY. Published by BMJ

${ }^{1}$ Department of Primary Care, University of Southampton, Southampton, UK

${ }^{2}$ MRC Epidemiology Unit, University of Cambridge, Cambridge, UK

${ }^{3}$ Department of Primary Care Health Sciences, University of Oxford, Oxford, UK

${ }^{4}$ Oxford University Hospitals NHS Trust, Oxford, UK

${ }^{5}$ Department of Population Health, University of Oxford, Oxford, UK

Correspondence to Dr Hajira Dambha-Miller; hajiradambha@doctors.org.uk

\section{ABSTRACT}

Objective To review evidence on routinely prescribed drugs in the UK that could upregulate or downregulate ACE2 and potentially affect COVID-19 disease.

Design Systematic review.

Data source MEDLINE, EMBASE, CINAHL, the Cochrane Library and Web of Science.

Study selection Any design with animal or human models examining a currently prescribed UK drug compared with a control, placebo or sham group, and reporting an effect on ACE2 level, activity or gene expression.

Data extraction and synthesis MEDLINE, EMBASE, CINAHL, the Cochrane Library, Web of Science and OpenGrey from inception to 1 April 2020. Methodological quality was assessed using the SYstematic Review Centre for Laboratory animal Experimentation (SYRCLE) risk-ofbias tool for animal studies and Cochrane risk-of-bias tool for human studies.

Results We screened 3360 titles and included 112 studies with 21 different drug classes identified as influencing ACE2 activity. Ten studies were in humans and one hundred and two were in animal models None examined ACE2 in human lungs. The most frequently examined drugs were angiotensin receptor blockers (ARBs) $(n=55)$ and ACE inhibitors (ACE-I) $(n=22)$. More studies reported upregulation than downregulation with $A C E-I$ $(n=22)$, ARBs $(n=55)$, insulin $(n=8)$, thiazolidinedione $(n=7)$ aldosterone agonists $(n=3)$, statins $(n=5)$, oestrogens $(n=5)$ calcium channel blockers $(n=3)$ glucagon-like peptide 1 (GLP-1) agonists $(n=2)$ and Non-steroidal antiinflammatory drugs (NSAIDs) $(n=2)$.

Conclusions There is an abundance of the academic literature and media reports on the potential of drugs that could attenuate or exacerbate COVID-19 disease. This is leading to trials of repurposed drugs and uncertainty among patients and clinicians concerning continuation or cessation of prescribed medications. Our review indicates that the impact of currently prescribed drugs on ACE2 has been poorly studied in vivo, particularly in human lungs where the SARS-CoV-2 virus appears to enact its pathogenic effects. We found no convincing evidence to justify starting or stopping currently prescribed drugs to influence outcomes of COVID-19 disease.
Strengths and limitations of this study

- Human and animal models both in vivo and in vitro were included for a comprehensive review.

- At the time of submission, this was the first systematic review on UK prescribed drugs that could alter ACE2 in COVID-19 disease.

- Meta-analysis was not possible due to heterogeneity.

- Methodological quality of the studies was low overall.

\section{INTRODUCTION}

The coronavirus SARS-CoV-2 that causes the COVID-19 disease is a global public health emergency. It has been reported in 190 countries with 4310786 confirmed cases and 290455 deaths as of 12 May 2020. Walker et al from the World Health Organization Collaborating Centre for Infectious Disease Modelling predicted that in the absence of mitigation strategies, the virus would infect 7 billion people and account for 40 million deaths this year alone. ${ }^{1}$ Efforts to shield the elderly $(60 \%$ reduction in social contacts) and interrupt transmission (40\% reduction in social contacts for the wider population) have reduced this number but further deaths are still expected. ${ }^{1}$ There is an urgent need for solutions. In the absence of a vaccination or effective treatment, there is growing interest in repurposing existing drugs for mitigation.

In particular, drugs affecting the reninangiotensin system (RAS) have been highlighted as potential candidates for further investigation. ${ }^{2} 3$ This is because the SARS-CoV-2 virus uses ACE2 receptors within the RAS for entry into lung alveolar epithelial cells. ${ }^{4}$ ACE2 has previously been shown to correlate with susceptibility to the SARS-CoV-1 virus, and the spike glycoprotein of this new virus binds to ACE2 
with even higher affinity. ${ }^{5}{ }^{6}$ Theoretically, altered ACE2 activity could, therefore, lead to a greater susceptibility to SARS-CoV-2. It could also cause greater severity of the infection. ${ }^{7}$ Previous studies suggest that dysregulation of ACE2 activity in the lungs could promote early neutrophil infiltration and subsequent uncontrolled activation of the RAS. ${ }^{8}$ In mice models, acute lung injury was observed in response to SARS-CoV-1 spike protein, so it is plausible that similar responses will be observed with SARS-CoV-2. ${ }^{9}$ This is particularly problematic in organs containing high ACE2 such as the lungs as it may contribute to cytokine release syndrome (cytokine storm) and the subsequent respiratory failure that has been observed in those who have died from the disease. ${ }^{7}$ Many prescribed drugs in common use are known to mediate effects through the RAS pathway. Over 45 million of these prescriptions were issued in the UK last year alone, and of these, 15 million were for ACE inhibitors (ACE-I) and angiotensin receptor blockers (ARBs). Acting through the RAS pathway, these drugs may impact ACE2 regulation but their role in the COVID-19 pandemic is not clear. Given the number of people that are potentially on these drugs, it has caused substantial public concern and clinical uncertainty about continuation or cessation of prescribed medications during the pandemic. Accordingly, we reviewed all existing evidence on routinely prescribed UK drugs that might alter ACE2 regulation. Understanding the drug effects on ACE2 given its role in COVID-19 disease could help reassure clinicians and the public in these uncertain times, or direct research on drugs that might attenuate or exacerbate transmission.

\section{METHODS}

Our review was conducted in accordance with Preferred Reporting Items for Systematic Reviews and Meta-Analyses (PRISMA) guidelines and our protocol was submitted for open-access publication before commencing our study. ${ }^{10}$

\section{Search strategy}

A systematic search in MEDLINE, EMBASE, CINAHL, the Cochrane Library and Web of Science was conducted from inception to the 1 April 2020. The full search strategy for all databases is shown in online supplemental material 1. The reference lists of recent reviews and included studies were screened. We also spoke to topic experts and screened OpenGrey for additional texts. No language limits or study design filters were applied.

\section{Study selection, inclusion and exclusion criteria}

The COVID-19 disease is still relatively new and there is limited research on drug therapies specific to the virus. In the interest of being comprehensive about potential drugs acting through ACE2, we were as inclusive as possible within our study selection. We included both animal and human models (in vivo and in vitro). Studies had to meet the following eligibility criteria: (1) measures ACE2 levels, activity or gene expression, (2) includes a drug that is currently available on a UK prescription according to the British National Formulary and (3) measures the effect of that drug against a placebo, control or sham group in an experimental design. Review articles were excluded but their reference lists were screened. Conference abstracts were included if sufficient detail could be elicited. We did not include studies in children under 18 years, or those examining drug effects in utero.

\section{Data extraction}

Four members of the team reviewed titles and abstracts for eligibility (AA, HD-M, CRW and SH). Full-text review, data extraction and quality assessment were carried out in duplicate using a piloted sheet. Any disagreement between authors was resolved by discussion. Data on the following study characteristics were extracted: (1) drug class, (2) drug name, (3) duration of treatment, (4) effect on ACE2 level (upregulation, downregulation and no effect), (5) model (human/rat), (6) site of ACE2 reception (lung, renal and cardiac), (7) study design, (8) study population, (9) sample size and (10) country. Given the urgency of our research question during the current pandemic, we extracted information from only what was available to us in the published text.

\section{Quality assessment}

Our review includes both animal and human models, therefore, quality assessment was carried out separately for these studies. Human studies were evaluated using the Cochrane risk-of-bias tool, which includes the following domains: random sequence generation, allocation concealment, blinding of participants and personnel, blinding of outcome assessment, incomplete outcome data, selective reporting and other sources of bias. ${ }^{11}$ Each domain was scored as low risk, unclear risk or high risk of bias. We classified the overall risk of bias as low if all domains were at low risk of bias, as high if at least one domain was at high risk of bias or as unclear if at least one domain was at unclear and no domain was at high risk of bias. Although this tool is specific to trials, all included studies were experimental designs and we, therefore, felt it appropriate to use. The methodological quality of animal studies was assessed using the SYstematic Review Centre for Laboratory animal Experimentation (SYRCLE) risk-of-bias tool that is based on the Cochrane risk-of-bias tool. ${ }^{12}$ SYRCLE's tool includes selection bias, performance bias, detection bias, attrition bias, reporting bias and other biases.

\section{Data analysis}

Owing to the mix of study designs and models, a metaanalysis was not appropriate. Narrative synthesis methods were used. We reviewed the metadata by tabulating the studies according to our inclusion/exclusion criteria, human/animal model, drug classes and effects on ACE2. The consistency in the number of studies and direction of any effects were considered. Where inconsistencies were identified in the effect of a drug between studies, 


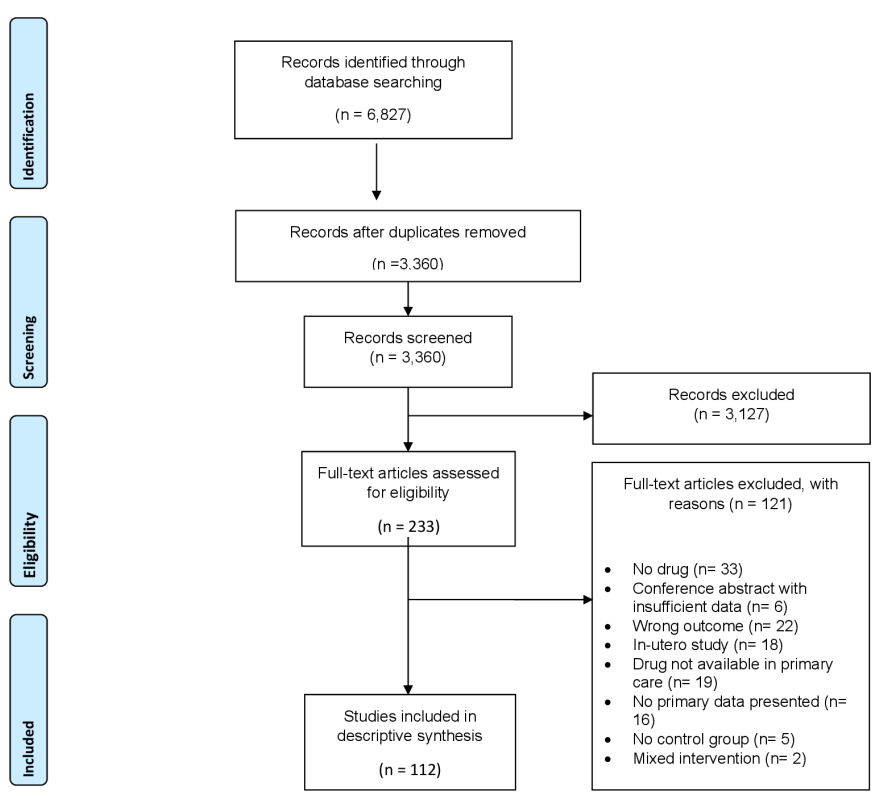

Figure 1 Preferred Reporting Items for Systematic Reviews and Meta-Analyses flow chart explaining the study inclusion process.

we looked at additional data such as methods, quality and outcome measurement for potential explanatory factors.

\section{Patient and public involvement (PPI)}

It was not possible to involve patients or the public in the design or conduct of our work due to the rapid timelines, but we have invited PPI representatives to help us with drafting a lay summary and in the dissemination of our findings.

\section{RESULTS}

We retrieved 6827 studies and screened 3360 after removing duplicates. Following title and abstract screening, 233 studies were screened by full text. We included 112 studies in the final review. The flow of studies is shown in a PRISMA diagram in figure 1 including the reasons for study exclusion at each stage. A baseline table of included studies is included in the online supplemental material 2.

\section{Study characteristics}

Table 1 shows the characteristics of the included studies. These originated from 17 different countries with the most common being China $(n=36)$, the USA $(n=22)$ and Japan $(n=18)$. There were 10 studies in humans ( 7 in vitro and 3 in vivo) and 102 in animal models (13 in vitro and 89 in vivo). Animal models included rats $(n=94)$, mice $(n=7)$ and canines $(n=1)$. The sample sizes for in vivo animal models ranged from 6 to 117. For in vivo human studies (table 2), sample sizes ranged from 8 to 375 but were not always reported. Participants were predominantly male and white with hypertension or diabetes, although the condition was not always stated. Most models examined ACE2 receptors in the heart or kidneys, only 5 of the 112 included studies reporting ACE2 levels in the lungs; these were all in animal models.

\section{Effects of drugs}

There were 21 different drug classes examined in the included studies. Table 2 tabulates only those that have been examined in human models. The mean drug exposure period ranged from $30 \mathrm{~min}$ for in vitro studies to 15 weeks for in vivo studies. The most common drug classes were ARBs $(\mathrm{n}=55)$ and ACE-I $(\mathrm{n}=22)$. Of the 55 studies that examined ARBs, 43 reported upregulation of ACE2 levels. Most of these studies were in rat models $(n=34)$ and examined cardiac ACE2 levels $(\mathrm{n}=27)$. For ACE-I, 17 out of 22 studies reported upregulation of ACE2. These were also mainly in rat models $(n=16)$ and measured cardiac ACE2 levels $(n=14)$. Of the five studies that assessed statins, these were all within rat models; three reported upregulation of ACE2, one reported downregulation and one reported no effect. Similarly, oestrogens were examined in five studies; three reported upregulation, one reported downregulation and one reported no effects. For calcium channel blockers; two out of the three studies reported upregulation of ACE2 levels and these were both in vivo rodent models. The third study was an in vitro human model that showed downregulation of ACE2 with a calcium channel blocker. There were three studies on aldosterone antagonists; all reporting increases in renal ACE2 levels within rat models.

Several diabetes drugs were evaluated and found to increase ACE2. For insulin, six out of eight studies reported upregulation of ACE2 (in mice and rat models). For thiazolidinediones, five out of seven studies reported upregulation (six mice/rate models and one of cerebral human cells in vitro). For glucagon-like peptide 1 (GLP-1) agonists, both included studies reported increases in ACE2. Similarly, for the one study examining DPP4 (Gliptans) inhibitors, it also reported an increase in ACE2. The only study measuring the effect of SGLT2 (Gliflozins) inhibitors reported a decrease in ACE2.

\section{Quality assessment}

The risk of bias across the studies has been shown in online supplemental material 3 using the SYRCLE's riskof-bias tool. In general, studies lacked blind allocation and outcome assessor blinding. They also frequently omitted information needed to make a thorough judgement on the risk of bias.

\section{DISCUSSION}

To our knowledge, this is the most comprehensive review of drugs prescribed in the UK that could act on ACE2 receptors and thus potentially affect COVID-19 disease. The ACE2 receptor is reported to be an essential contributor to SARS-CoV-2 entry into the nasopharynx and lungs and the subsequent inflammation that leads to severe acute respiratory distress syndrome. ${ }^{13} 14$ Our review examined drugs across human and animal 
Table 1 Characteristics and key findings of included studies

\begin{tabular}{|c|c|c|c|c|c|c|}
\hline Drug class & $\begin{array}{l}\text { Sample } \\
\text { size, } \\
\text { median } \\
\text { (range) } \\
\end{array}$ & $\begin{array}{l}\text { Exposure to } \\
\text { treatment, } \\
\text { mean (SD) }\end{array}$ & $\begin{array}{l}\text { Effect on ACE2 } \\
\text { expression, } \\
\text { levels or } \\
\text { activity } \\
\text { (number of } \\
\text { studies)* }^{*}\end{array}$ & $\begin{array}{l}\text { Model } \\
\text { tested } \\
\text { (number } \\
\text { of } \\
\text { studies)* }\end{array}$ & $\begin{array}{l}\text { Site of ACE2 } \\
\text { receptor } \\
\text { measurement } \\
\text { (number of } \\
\text { studies)* }^{\star}\end{array}$ & $\begin{array}{l}\text { Condition of subjects } \\
\text { (number of studies)* }^{*}\end{array}$ \\
\hline ACE inhibitors ${ }^{27-36}$ & $32(7-375)$ & 4 weeks (3) & $\begin{array}{l}\text { Increase }(n=17) \\
\text { Decrease }(n=1) \\
\text { No effect }(n=4)\end{array}$ & $\begin{array}{l}\text { Rats, in } \\
\text { vivo }(n=16) \\
\text { Humans, in } \\
\text { vivo }(n=2) \\
\text { Other }(n=4)\end{array}$ & $\begin{array}{l}\text { Cardiac }(n=14) \\
\text { Hepatic }(n=2) \\
\text { Renal }(n=2) \\
\text { Not stated }(n=2) \\
\text { Other }(n=3)\end{array}$ & $\begin{array}{l}\text { Heart disease/heart failure } \\
(n=7) \\
\text { Hypertension }(n=3) \\
\text { Diabetes }(n=3) \\
\text { Healthy }(n=2) \\
\text { Other }(n=1) \\
\text { Not stated }(n=6)\end{array}$ \\
\hline $\begin{array}{l}\text { Aldosterone } \\
\text { antagonists }^{37-39}\end{array}$ & $63(28-75)$ & 4 weeks (4) & $\begin{array}{l}\text { Increase }(n=3) \\
\text { Decrease }(n=0) \\
\text { No effect }(n=0)\end{array}$ & $\begin{array}{l}\text { Rats, in } \\
\text { vivo }(n=3)\end{array}$ & Renal $(n=3)$ & $\begin{array}{l}\text { Diabetes }(n=1) \\
\text { Renal disease }(n=1) \\
\text { Hepatic dysfunction }(n=1)\end{array}$ \\
\hline Beta blockers ${ }^{6390}$ & $52(44-62)$ & 4 weeks (2) & $\begin{array}{l}\text { Increase }(n=0) \\
\text { Decrease }(n=0) \\
\text { No effect }(n=2)\end{array}$ & $\begin{array}{l}\text { Rats, in } \\
\text { vivo }(n=1) \\
\text { Rats, in } \\
\text { vitro }(n=1)\end{array}$ & Cardiac $(n=2)$ & Hypertension (n=2) \\
\hline $\begin{array}{l}\text { Calcium channel } \\
\text { blockers }\end{array}$ & 117 (N/A) & 3 weeks (1) & $\begin{array}{l}\text { Increase }(n=2) \\
\text { Decrease }(n=1) \\
\text { No effect }(n=0)\end{array}$ & $\begin{array}{l}\text { Rats, in } \\
\text { vivo }(n=2) \\
\text { Human, in } \\
\text { vitro }(n=1\end{array}$ & $\begin{array}{l}\text { Hepatic }(n=1) \\
\text { Cardiac }(n=1) \\
\text { Cerebral }(n=1)\end{array}$ & $\begin{array}{l}\text { Healthy }(n=2) \\
\text { Hypertension }(n=1)\end{array}$ \\
\hline GABA analogues $^{94}$ & $8(N / A)$ & $\begin{array}{l}3 \text { weeks } \\
(\mathrm{N} / \mathrm{A})\end{array}$ & $\begin{array}{l}\text { Increase }(n=0) \\
\text { Decrease }(n=1) \\
\text { No effect }(n=0)\end{array}$ & $\begin{array}{l}\text { Rats, in } \\
\text { vivo }(n=1)\end{array}$ & Cerebral $(n=1)$ & Heathy $(n=1)$ \\
\hline GLP-1 agonists ${ }^{9395}$ & $38(24-54)$ & 3 weeks (1) & $\begin{array}{l}\text { Increase }(n=2) \\
\text { Decrease }(n=0) \\
\text { No effect }(n=0)\end{array}$ & $\begin{array}{l}\text { Rats, in } \\
\text { vivo }(n=2)\end{array}$ & $\begin{array}{l}\text { Cardiac }(n=1) \\
\text { Lung }(n=1)\end{array}$ & $\begin{array}{l}\text { Diabetic }(n=1) \\
\text { Healthy }(n=1)\end{array}$ \\
\hline Insulin $96-103$ & $57(8-84)$ & 6 weeks (6) & $\begin{array}{l}\text { Increase }(n=6) \\
\text { Decrease }(n=1) \\
\text { No effect }(n=1)\end{array}$ & $\begin{array}{l}\text { Mice, in } \\
\text { vivo }(n=4) \\
\text { Mice, in } \\
\text { vitro }(n=1) \\
\text { Rats, in } \\
\text { vivo }(n=2) \\
\text { Rats, in } \\
\text { vitro }(n=1)\end{array}$ & $\begin{array}{l}\text { Renal }(n=5) \\
\text { Cardiac }(n=2)\end{array}$ & $\begin{array}{l}\text { Diabetes }(n=7) \\
\text { Healthy }(n=1)\end{array}$ \\
\hline Ivabradine $e^{104}$ & 24 (N/A) & $\begin{array}{l}12 \text { weeks } \\
(\mathrm{N} / \mathrm{A})\end{array}$ & $\begin{array}{l}\text { Increase }(n=1) \\
\text { Decrease }(n=0) \\
\text { No effect }(n=0)\end{array}$ & $\begin{array}{l}\text { Canine, in } \\
\text { vivo }(n=1)\end{array}$ & Cardiac $(n=1)$ & Heart failure $(n=1)$ \\
\hline NSAIDs $^{105106}$ & $18(\mathrm{~N} / \mathrm{A})$ & 8 weeks $(0)$ & $\begin{array}{l}\text { Increase }(n=2) \\
\text { Decrease }(n=0) \\
\text { No effect }(n=0)\end{array}$ & $\begin{array}{l}\text { Rats, in } \\
\text { vivo }(n=2)\end{array}$ & Cardiac $(n=2)$ & Diabetic $(n=2)$ \\
\hline
\end{tabular}

Continued 
Table 1 Continued

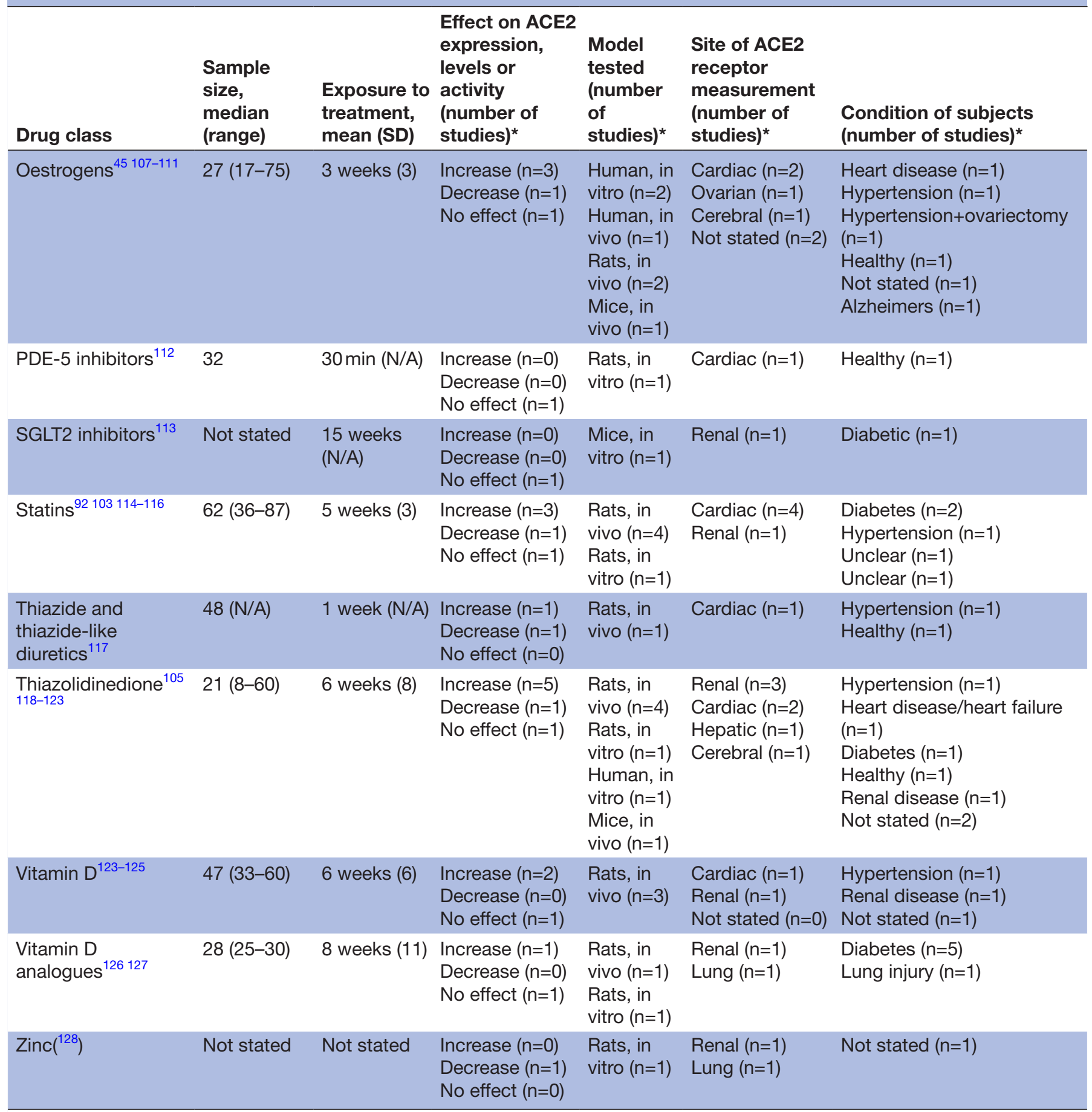

*Studies reporting on multiple sites or in multiple models have been listed separately and appear more than once in the table. GABA, gamma-Aminobutyric acid; GLP-1, glucagon-like peptide 1; PDE-5 inhibitor, phosphodiesterase type 5 inhibitor.

models, and we found a number of studies reporting upregulation of ACE2 levels in response to ACE-I $(\mathrm{n}=22)$, ARBs $(\mathrm{n}=55)$, insulin $(\mathrm{n}=8)$, thiazolidinedione $(n=7)$ aldosterone agonists $(n=3)$, statins $(n=5)$, oestrogens $(n=5)$ calcium channel blockers $(n=3)$ GLP-1 agonists $(n=2)$ and NSAIDs $(n=2)$. However, these drugs were poorly studied in vivo within the lungs or nasopharynx of humans, where they are likely to matter most in influencing the severity of outcomes of COVID-19 disease.

We observed that the most frequent drugs to upregulate ACE2 are also those prescribed in people with diabetes or cardiovascular disease. Mortality rates from COVID-19 have been high in this group..$^{13}{ }^{15-17}$ Notably, these are also conditions with a high prevalence among Black, Asian and Minority Ethnic groups who have had 
Table 2 Summary of studies characteristics with human models

\begin{tabular}{|c|c|c|c|c|c|c|}
\hline Drug class & $\begin{array}{l}\text { Sample size, } \\
\text { median (range) }\end{array}$ & $\begin{array}{l}\text { Exposure to } \\
\text { treatment, } \\
\text { mean (SD) }\end{array}$ & $\begin{array}{l}\text { Effect } \\
\text { on ACE2 } \\
\text { expression, } \\
\text { levels or } \\
\text { activity } \\
\text { (number of } \\
\text { studies) }\end{array}$ & $\begin{array}{l}\text { Model } \\
\text { tested }\end{array}$ & $\begin{array}{l}\text { Site of ACE2 } \\
\text { receptors }\end{array}$ & Condition of subject \\
\hline $\begin{array}{l}\text { Angiotensin receptor } \\
\text { blockers }\end{array}$ & $46.5(8-80)$ & 15 weeks (6) & $\begin{array}{l}\text { Increase }(n=2) \\
\text { Decrease }(n=1) \\
\text { No effect }(n=1)\end{array}$ & $\begin{array}{l}\text { In vivo } \\
(n=3) \\
\text { In vitro } \\
(n=1)\end{array}$ & $\begin{array}{l}\text { Urinary }(n=1) \\
\text { Serum }(n=1) \\
\text { Renal }(n=1) \\
\text { Not stated } \\
(n=1)\end{array}$ & $\begin{array}{l}\text { Diabetes }(n=1) \\
\text { Hypertension }(n=1) \\
\text { Hypertension+diabetes } \\
(n=1) \\
\text { Diabetic+chronic kidney } \\
\text { disease }(n=1)\end{array}$ \\
\hline ACE inhibitors & $228(80-375)$ & $\begin{array}{l}12 \text { weeks } \\
(\mathrm{N} / \mathrm{A})\end{array}$ & $\begin{array}{l}\text { Increase }(n=1) \\
\text { Decrease }(n=1)\end{array}$ & $\begin{array}{l}\text { In vitro } \\
(n=2)\end{array}$ & $\begin{array}{l}\text { Renal }(n=1) \\
\text { Unclear } \\
(n=1)\end{array}$ & $\begin{array}{l}\text { Diabetic+chronic kidney } \\
\text { disease }(n=1) \\
\text { Unclear }(n=1)\end{array}$ \\
\hline Oestrogen & $36(\mathrm{~N} / \mathrm{A})$ & 1 day $(\mathrm{N} / \mathrm{A})$ & $\begin{array}{l}\text { Increase }(n=2) \\
\text { No effect }(n=1)\end{array}$ & $\begin{array}{l}\text { In vitro } \\
(n=3)\end{array}$ & $\begin{array}{l}\text { Cardiac } \\
(n=1) \\
\text { Umbilical } \\
(n=1) \\
\text { Not stated } \\
(n=1)\end{array}$ & $\begin{array}{l}\text { Heart problems }(n=1) \\
\text { Healthy }(n=1) \\
\text { Not stated }(n=1)\end{array}$ \\
\hline
\end{tabular}

disproportionally high mortality rates from COVID-19 disease. ${ }^{18}$ To date, much of this evidence has been limited to clinical commentaries or case reports. Larger cohorts are emerging but have not yet adequately considered a range of potential confounders including comorbidities, age, sex, deprivation or household numbers which might be more important than prescribed medication in the spread, susceptibility and severity of the disease. For example, in a cohort of 191 people who were infected with the virus in Wuhan, 87\% (approximately 155) of those who died had coronary heart disease and $47 \%$ (approximately 90) had diabetes. ${ }^{19}$ These conditions are associated with an increased risk of death but were not considered as covariates in the analysis. Irrespective of ACE2, people with diabetes are more susceptible to worse infection as the low-grade chronic inflammation and hyperglycaemia associated with the condition results in impaired immune responses with lower interleukin 1 (IL-1), IL-6, tumor necrosis factor (TNF)- $\alpha$ and delayed mobilisation of immune cells in response to pathogens. ${ }^{20}$ This comorbidity, like many other confounders, is highly relevant when examining the risk of death with COVID-19 disease.

This lack of adequate adjustment for existing conditions is highlighted by Sommerstein $e t$ al in their editorial on ACE-I and ARBs in COVID-19. ${ }^{16}$ They also propose that existing comorbidities such as heart failure may be independently linked to SARS-CoV-2 transmission and severity, and the subsequent poor pulmonary outcomes that are observed in these patients. Indeed, in mice models, arterial hypertension, atrial fibrillation and type 2 diabetes have been shown to upregulate ACE2 levels irrespective of medications. ${ }^{21} 22$ Moreover, ACE2 levels are higher in men and with increasing age. ${ }^{23}$ Most of the published data on deaths in COVID-19 disease report that men of increasing age are particularly susceptible to poor outcomes. $^{1324}$

Our review has also highlighted the variable ACE2 levels in different parts of the body with most of the existing literature focussing on renal and cardiac levels. Responses to drugs may vary depending on cell type and location. Although the lung ACE2 is important to COVID19 , it is unclear if overall COVID-19 mortality might be attenuated by cardiovascular ACE-2 activity levels. We also observed variations in ACE2 levels with drug exposure duration which was relatively short among included studies in our review. It is uncertain how dysregulation might continue after starting or stopping these medications. It is also unclear how the observed effects among included studies would translate in vivo in humans and 
what the net effect on receptor access to the COVID-19 virus is; access to the receptor by the virus may be competitively inhibited by the presence of drugs which also attach to the receptor, so whether upregulation is the key factor in practice is unclear. This is particularly challenging to understand as we found a paucity of data demonstrating the effect of prescribed drugs on ACE2 in the lungs or nasopharynx, where the SARS-CoV-2 virus appears to enact its pathogenic effects. Our results, therefore, do not provide convincing evidence on the role of any currently prescribed UK drugs acting through ACE2 regulation that could affect COVID-19 disease. Finally, we found a disproportionate number of studies reporting upregulation or 'positive effects' of drugs on ACE2, compared with studies reporting no effect or downregulation. This may reflect a publication bias that is well established in the literature, especially among animal models. ${ }^{25} 26$

\section{Strengths and limitations}

We carried out a comprehensive and systematic search of the literature. To our knowledge, at the time of submission (April 2020), this is the first review on the subject. We did not include language restrictions but non-English language studies in the international literature might not have been indexed in the databases we searched. Given the rate of new publications on COVID-19, it is also possible that our search and results may not be up to date. Owing to the limited research on this novel virus, it was necessary to be as inclusive as possible and we, therefore, considered both animal and human models to look for any drugs acting through ACE2 with potential to affect COVID-19 outcomes. While this inclusive approach may offer insights, the heterogeneity across models makes it hard to interpret findings or translate them directly to patients. We did not formally assess heterogeneity but this is likely as we had multiple different models including animal, human, in vitro, in vivo as well as different body sites (heart, lung and kidney) Future studies are needed that can quantify effects through meta-analysis, and examine dose responses. Although we were robust in our methodological approach to this review, we were also aware of the urgency to report our findings in the current pandemic. We, therefore, did not contact authors for more information about their studies beyond what was published. We observed frequent omission of information that would have allowed us to carry out a more detailed quality assessment. Had we pursued this information; the quality assessment of included papers may well have been higher. At present, all studies were high risk of bias, which is a limitation of this review.

\section{CONCLUSION}

We reviewed the evidence on routinely prescribed drugs in the UK that could upregulate or downregulate ACE2, and thus potentially affect COVID-19 disease. Our review indicates that currently prescribed drugs have been poorly studied in vivo within the lungs of humans. Until there is better evidence, we cannot recommend starting or stopping prescribed medications during the COVID-19 pandemic.

\section{Twitter Hajira Dambha-Miller @HDambhaMiller}

Acknowledgements We would like to thank Professor Julia Hippisley-Cox for her early contributions to this project.

Contributors HD-M contributed to the design of the study, wrote the analysis plan, conducted the analysis, drafted and revised the paper. AA contributed to the design of the study, led the analysis, drafted and revised the paper. CRW and SH contributed to the screening of studies, data extraction and revised the paper. SK contributed to screening of studies. NI revised the paper. SJG and PL contributed to the design of the study and revised the paper. HD-M was the guarantor.

Funding The Southampton, Cambridge and Oxford Primary Care Departments are members of the NIHR School for Primary Care Research and supported by NIHR Research Funds. The University of Cambridge has received salary support in respect of SJG from the National Health Service (NHS) in the East of England through the Clinical Academic Reserve. SJG is supported by an MRC Epidemiology Unit programme: MC_UU_12015/4. HD-M is an NIHR Academic Clinical Lecturer. The views expressed are those of the author(s) and not necessarily those of the NHS, the NIHR or the Department of Health and Social Care

Competing interests None declared.

Patient and public involvement Patients and/or the public were involved in the design, or conduct, or reporting, or dissemination plans of this research. Refer to the Methods section for further details.

Patient consent for publication Not required.

Provenance and peer review Not commissioned; externally peer reviewed.

Data availability statement Data are available upon reasonable request.

Open access This is an open access article distributed in accordance with the Creative Commons Attribution 4.0 Unported (CC BY 4.0) license, which permits others to copy, redistribute, remix, transform and build upon this work for any purpose, provided the original work is properly cited, a link to the licence is given, and indication of whether changes were made. See: https://creativecommons.org/ licenses/by/4.0/.

ORCID iDs

Hajira Dambha-Miller http://orcid.org/0000-0003-0175-443X

Ali Albasri http://orcid.org/0000-0001-7805-1965

Sam Hodgson http://orcid.org/0000-0002-5610-850X

Nazrul Islam http://orcid.org/0000-0003-3982-4325

Paul Little http://orcid.org/0000-0003-3664-1873

\section{REFERENCES}

1 Gt Walker P, Whittaker C, Watson O, et al. The global impact of COVID-19 and strategies for mitigation and suppression.

2 Patel AB, Verma A. COVID-19 and angiotensin-converting enzyme inhibitors and angiotensin receptor blockers. JAMA;323:1769-70.

3 Fang L, Karakiulakis G, Roth M. Are patients with hypertension and diabetes mellitus at increased risk for COVID-19 infection? Lancet Respir Med 2020;8:e21.

$4 \mathrm{Jia} \mathrm{H}$. Pulmonary angiotensin-converting enzyme 2 (ACE2) and inflammatory lung disease. Shock 2016;46:239-48.

5 Hofmann H, Geier M, Marzi A, et al. Susceptibility to SARS coronavirus $S$ protein-driven infection correlates with expression of angiotensin converting enzyme 2 and infection can be blocked by soluble receptor. Biochem Biophys Res Commun 2004;319:1216-21.

6 Wrapp D, Wang N, Corbett KS, et al. Cryo-Em structure of the 2019-nCoV spike in the prefusion conformation. Science 2020;367:1260-3.

7 Shi Y, Wang Y, Shao C, et al. COVID-19 infection: the perspectives on immune responses. Cell Death Differ 2020;27:1451-4.

8 Sodhi CP, Wohlford-Lenane C, Yamaguchi Y, et al. Attenuation of pulmonary ACE2 activity impairs inactivation of des-Arg ${ }^{9}$ bradykinin/BKB1R axis and facilitates LPS-induced neutrophil infiltration. Am J Physiol Lung Cell Mol Physiol 2018;314:L17-31.

9 Kuba K, Imai Y, Rao S, et al. A crucial role of angiotensin converting enzyme 2 (ACE2) in SARS coronavirus-induced lung injury. Nat Med 2005;11:875-9. 
10 Dambha-Miller H, Albasri A, Hodgson S, et al. Drug treatments affecting ACE2 in COVID-19 infection: a systematic review protocol. BJGP Open 2020;4. doi:10.3399/bjgpopen20X101115. [Epub ahead of print: 25 Aug 2020].

11 Higgins JPT, Altman DG, Gøtzsche PC, et al. The Cochrane collaboration's tool for assessing risk of bias in randomised trials. BMJ 2011;343:d5928.

12 Hooijmans CR, Rovers MM, de Vries RBM, et al. SYRCLE's risk of bias tool for animal studies. BMC Med Res Methodol 2014;14:43.

13 Wu C, Chen X, Cai Y, et al. Risk factors associated with acute respiratory distress syndrome and death in patients with coronavirus disease 2019 pneumonia in Wuhan, China. JAMA Intern Med 2020;180:934.

14 Gorbalenya AE, Baker SC, Baric RS, et al. Severe acute respiratory syndrome-related coronavirus: the species and its viruses-a statement of the coronavirus Study Group. bioRxiv. [Epub ahead of print: 11 Feb 2020].

15 Williamson EJ, Walker AJ, Bhaskaran $\mathrm{K}$, et al. Factors associated with COVID-19-related death using OpenSAFELY. Nature 2020:584:430-6.

16 Sommerstein R, Kochen MM, Messerli FH, et al. Coronavirus disease 2019 (COVID-19): do angiotensin-converting enzyme Inhibitors/Angiotensin receptor blockers have a biphasic effect? $J$ Am Heart Assoc 2020;9:e016509.

17 Chen $\mathrm{Y}$, Gong X, Wang L, et al. Effects of hypertension, diabetes and coronary heart disease on COVID-19 diseases severity: a systematic review and meta-analysis. medRxiv2020. 2020.03.25.20043133

18 BAME COVID-19 DEATHS - What do we know? Rapid Data \& Evidence Review - CEBM. Available: https://www.cebm.net/covid19/bame-covid-19-deaths-what-do-we-know-rapid-data-evidencereview/ [Accessed 6 May 2020].

19 Zhou F, Yu T, Du R, et al. Clinical course and risk factors for mortality of adult inpatients with COVID-19 in Wuhan, China: a retrospective cohort study. Lancet 2020;395:1054-62.

20 lacobellis G. COVID-19 and diabetes: can DPP4 inhibition play a role? Diabetes Res Clin Pract 2020;162:108125.

21 Úri K, Fagyas M, Mányiné Siket I, et al. New perspectives in the renin-angiotensin-aldosterone system (RaaS) IV: circulating ACE2 as a biomarker of systolic dysfunction in human hypertension and heart failure. PLoS One 2014:9:e87845.

22 Zhou T, Wang Z, Fan J, et al. Angiotensin-Converting enzyme-2 overexpression improves atrial remodeling and function in a canine model of atrial fibrillation. J Am Heart Assoc 2015;4:e001530.

23 Fernández-Atucha A, Izagirre A, Fraile-Bermúdez AB, et al. Sex differences in the aging pattern of renin-angiotensin system serum peptidases. Biol Sex Differ 2017;8:5.

24 Deng S-Q, Peng H-J. Characteristics of and public health responses to the coronavirus disease 2019 outbreak in China. J Clin Med 2020;9:575.

25 Murad MH, Chu H, Lin L, et al. The effect of publication bias magnitude and direction on the certainty in evidence. BMJ Evid Based Med 2018;23:84-6.

26 Conradi U, Joffe AR. Publication bias in animal research presented at the 2008 Society of critical care medicine conference. BMC Res Notes 2017;10:262.

27 Yang Z, Yu X, Cheng L, et al. Effects of enalapril on the expression of cardiac angiotensin-converting enzyme and angiotensinconverting enzyme 2 in spontaneously hypertensive rats. Arch Cardiovasc Dis 2013;106:196-201.

28 Azis NA, Agarwal R, Ismail NM, et al. Blood pressure lowering effect of Ficus deltoidea var kunstleri in spontaneously hypertensive rats: possible involvement of renin-angiotensin-aldosterone system, endothelial function and anti-oxidant system. Mol Biol Rep 2019;46:2841-9.

29 Hao X-Q, Zhang S-Y, Cheng X-C, et al. Imidapril inhibits right ventricular remodeling induced by low ambient temperature in broiler chickens. Poult Sci 2013;92:1492-7.

30 Jessup JA, Gallagher PE, Averill DB, et al. Effect of angiotensin II blockade on a new congenic model of hypertension derived from transgenic Ren-2 rats. Am J Physiol Heart Circ Physiol 2006;291:H2166-72.

31 Huang M-liang, Li X, Meng Y, et al. Upregulation of angiotensinconverting enzyme (ACE) 2 in hepatic fibrosis by ACE inhibitors. Clin Exp Pharmacol Physiol 2010;37:e1-6.

32 Wang G, Zhang Q, Yuan W, et al. Enalapril protects against myocardial ischemia/reperfusion injury in a swine model of cardiac arrest and resuscitation. Int $J$ Mol Med 2016;38:1463-73.

33 Wang Y, Li C, Ouyang Y, et al. Cardioprotective effects of Qishenyiq mediated by angiotensin II type 1 receptor blockade and enhancing angiotensin-converting enzyme 2. Evid Based Complement Alternat Med 2012;2012:1-9.

34 Burchill L, Velkoska E, Dean RG, et al. Acute kidney injury in the rat causes cardiac remodelling and increases angiotensin-converting enzyme 2 expression. Exp Physiol 2008;93:622-30.

35 Zhang Y, Wang B, Wu J, et al. Role of ACE inhibitor and AT1 blockade on cardiac ACE and ACE2 expression in mice with unilateral ureteral ligation. Int J Cardiol 2011;152:S97.

36 Zhang Y, Li B, Ma L, et al. GW25-e0791 role of AT1 blockade on cardiac ACE2 and Mas expression in hypertensive rats. J Am Coll Cardiol 2014;64:C179.

37 Bernardi S, Toffoli B, Zennaro C, et al. Aldosterone effects on glomerular structure and function. J Renin Angiotensin Aldosterone Syst 2015;16:730-8.

38 Dong D, Fan T-T, Ji Y-S, et al. Spironolactone alleviates diabetic nephropathy through promoting autophagy in podocytes. Int Urol Nephrol 2019;51:755-64.

39 Kong E-L, Zhang J-M, An N, et al. Spironolactone rescues renal dysfunction in obstructive jaundice rats by upregulating ACE2 expression. J Cell Commun Signal 2019;13:17-26.

40 Hiroi N, Yoshihara ASM, et al. Effects of olmesartan to the ACE2/ Ang-(1-7)/Mas receptor endocrine society axis on essential hypertension patients. Endocrine Reviews 2014;35 http://press. endocrine.org/doi/abs/10.1210/endo-meetings.2014.CE.8.MON0868\%0Ahttp://ovidsp.ovid.com/ovidweb.cgi?T=JS\&PAGE= reference\&D=emed15\&NEWS $=\mathrm{N} \& A N=72338547$

41 Li Y-qin, Wu J-juan, Gao D-feng, et al. [The impact of telmisartan on angiotensin converting enzyme 2 mRNA expression in monocytederived macrophages of diabetic hypertensive patients]. Zhonghua Nei Ke Za Zhi 2013;52:26-9.

42 Wang $\mathrm{X}$, Ye Y, Gong $\mathrm{H}$, et al. The effects of different angiotensin II type 1 receptor blockers on the regulation of the ACE-Angll-AT1 and ACE2-Ang(1-7)-Mas axes in pressure overload-induced cardiac remodeling in male mice. J Mol Cell Cardiol 2016;97:180-90.

43 Soler MJ, Ye M, Wysocki J, et al. Localization of ACE2 in the renal vasculature: amplification by angiotensin II type 1 receptor blockade using telmisartan. Am J Physiol Renal Physiol 2009;296:F398-405.

44 Senador D, Key M, Brosnihan KB, et al. Cardiovascular interactions between losartan and fructose in mice. J Cardiovasc Pharmacol Ther 2010;15:68-77.

45 Abdelkader NF, Abd El-Latif AM, Khattab MM. Telmisartan/17ßestradiol mitigated cognitive deficit in an ovariectomized rat model of Alzheimer's disease: modulation of ACE1/ACE2 and AT1/AT2 ratio. Life Sci 2020;245:117388.

46 Li Y, Cai S, Wang Q, et al. Valsartan attenuates intimal hyperplasia in balloon-injured rat aortic arteries through modulating the angiotensin-converting enzyme 2-angiotensin-(1-7)-Mas receptor axis. Arch Biochem Biophys 2016;598:11-17.

47 Zhang Y, Li B, Wang B, et al. Alteration of cardiac ACE2/Mas expression and cardiac remodelling in rats with aortic constriction. Chin J Physiol 2014;57:335-42.

48 Minakawa M, Fukui K, Ji K, et al. Olmesartan improves left ventricular function in pressure-overload hypertrophied rat heart by blocking angiotensin II receptor with synergic effects of upregulation of angiotensin converting enzyme 2. Ther Adv Cardiovasc Dis 2009;3:103-11.

49 Sabry MM, Mahmoud MM, Shoukry HS, et al. Interactive effects of apelin, renin-angiotensin system and nitric oxide in treatment of obesity-induced type 2 diabetes mellitus in male albino rats. Arch Physiol Biochem 2019;125:244-54.

50 Li C-M ZX-H, Zhang Y-Y, et al. The effect of irbesartan on myocardial interstitial fibrosis in diabetic rats. African Journal Of Pharmacy And Pharmacology 2011;5:1360-4

51 Abdel-Fattah MM, Messiha BAS, Mansour AM. Modulation of brain ACE and ACE2 may be a promising protective strategy against cerebral ischemia/reperfusion injury: an experimental trial in rats. Naunyn Schmiedebergs Arch Pharmacol 2018;391:1003-20.

52 Arumugam S, Thandavarayan RA, Palaniyandi SS, et al. Candesartan cilexetil protects from cardiac myosin induced cardiotoxicity via reduction of endoplasmic reticulum stress and apoptosis in rats: involvement of ACE2-Ang (1-7)-mas axis. Toxicology 2012;291:139-45.

53 Kidoguchi S, Sugano N, Takane K, et al. Azilsartan causes natriuresis due to its sympatholytic action in kidney disease. Hypertension Research 2019;42:1507-17.

54 Liang B, Li Y, Han Z, et al. ACE2-Ang (1-7) axis is induced in pressure overloaded rat model. Int $\mathrm{J}$ Clin Exp Pathol 2015:8:1443-50.

55 Awwad ZM, El-Ganainy SO, ElMallah Al, et al. Telmisartan and captopril ameliorate pregabalin-induced heart failure in rats. Toxicology 2019;428:152310. 
56 Sukumaran V, Veeraveedu PT, Gurusamy N, et al. Telmisartan acts through the modulation of ACE-2/ANG 1-7/mas receptor in rats with dilated cardiomyopathy induced by experimental autoimmune myocarditis. Life Sci 2012;90:289-300.

57 Yang D, Lin Z, Ni Y, et al. A1059 Telmisartan upregulates ACE2-Ang(1-7)-Mas axis and affects retinal vessel endothelial cell apoptosis. $J$ Hypertension 2018;36:e11.

58 Takai S, Jin D, Aritomi S, et al. Powerful vascular protection by combining cilnidipine with valsartan in stroke-prone, spontaneously hypertensive rats. Hypertens Res 2013;36:342-8.

59 Zhong J-C, Ye J-Y, Jin H-Y, et al. Telmisartan attenuates aortic hypertrophy in hypertensive rats by the modulation of ACE2 and profilin-1 expression. Regul Pept 2011;166:90-7.

60 Zhao Y, Ma R, Yu X, et al. AHU377+Valsartan (LCZ696) modulates renin-angiotensin system (ras) in the cardiac of female spontaneously hypertensive rats compared with valsartan. $J$ Cardiovasc Pharmacol Ther 2019;24:450-9.

61 Agata J, Ura N, Yoshida H, et al. Olmesartan is an angiotensin II receptor blocker with an inhibitory effect on angiotensin-converting enzyme. Hypertens Res 2006;29:865-74.

62 Igase M, Kohara K, Nagai T, et al. Increased expression of angiotensin converting enzyme 2 in conjunction with reduction of neointima by angiotensin II type 1 receptor blockade. Hypertens Res 2008;31:553-9.

63 Igase M, Strawn WB, Gallagher PE, et al. Angiotensin II AT receptors regulate ACE2 and angiotensin- $(-7)$ expression in the aorta of spontaneously hypertensive rats. Am J Physiol Heart Circ Physiol 2005;289:H1013-9.

64 Wösten-van Asperen RM, Lutter R, Specht PA, et al. Acute respiratory distress syndrome leads to reduced ratio of ACE/ACE2 activities and is prevented by angiotensin-(1-7) or an angiotensin II receptor antagonist. $J$ Pathol 2011;225:618-27.

65 Ohshima K, Mogi M, Nakaoka H, et al. Possible role of angiotensinconverting enzyme 2 and activation of angiotensin II type 2 receptor by angiotensin-(1-7) in improvement of vascular remodeling by angiotensin II type 1 receptor blockade. Hypertension 2014;63:e53-9.

66 Gallagher PE, Ferrario CM, Tallant EA. Regulation of ACE2 in cardiac myocytes and fibroblasts. Am J Physiol Heart Circ Physio 2008;295:H2373-9.

67 Feng P, Wu Z, Liu H, et al. Electroacupuncture Improved Chronic Cerebral Hypoperfusion-Induced Anxiety-Like Behavior and Memory Impairments in Spontaneously Hypertensive Rats by Downregulating the ACE/Ang II/AT1R Axis and Upregulating the ACE2/Ang-(1-7)/MasR Axis. Neural Plast 2020;2020:1-12.

68 Song R, Preston G, Yosypiv IV. Ontogeny of angiotensin-converting enzyme 2. Pediatr Res 2012;71:13-19.

69 Lezama-Martinez D, Flores-Monroy J, Fonseca-Coronado S, et al Combined antihypertensive therapies that increase expression of cardioprotective biomarkers associated with the ReninAngiotensin and Kallikrein-Kinin systems. J Cardiovasc Pharmacol 2018;72:291-5.

70 Abe M, Oikawa O, Okada K, et al. Urinary angiotensin-converting enzyme 2 increases in diabetic nephropathy by angiotensin II type receptor blocker olmesartan. J Renin Angiotensin Aldosterone Syst 2015;16:159-64.

71 Shimada KK K, Kinouchi T, Yagi KTY, et al. International stroke conference and nursing symposium poster presentations. Stroke20 11;42:e111-350.

72 Ishiyama Y, Gallagher PE, Averill DB, et al. Upregulation of angiotensin-converting enzyme 2 after myocardial infarction by blockade of angiotensin II receptors. Hypertension 2004;43:970-6.

73 Guo J, Lu W, Wang X, et al. Protective effects of telmisartan in a rat model of pulmonary arterial hypertension. Experimental and Clinical Cardiology 2014;20:2429-37.

74 Yisireyili M, Uchida Y, Yamamoto K, et al. Angiotensin receptor blocker irbesartan reduces stress-induced intestinal inflammation via AT1A signaling and ACE2-dependent mechanism in mice. Brain Behav Immun 2018:69:167-79.

75 Suh SH, Choi HS, Kim CS, et al. Olmesartan attenuates kidney fibrosis in a murine model of Alport syndrome by suppressing tubular expression of TGF $\beta$. Int J Mol Sci 2019;20:3843.

76 Iwanami J, Mogi M, Tsukuda K, et al. Role of angiotensin-converting enzyme 2/angiotensin-(1-7)/Mas axis in the hypotensive effect of azilsartan. Hypertens Res 2014;37:616-20.

77 G.-H Y. The strategy of rennin-angiotensin system blockers reduce the indoxyl sulfate-mediated renal damage on the duration of acute kidney injury. Nephrology 2014;19:161-2.

78 Ichikawa H, Narita I, Narita M, et al. Blood pressure-independent effect of olmesartan on albuminuria in mice overexpressing renin: Its beneficial role in the ACE2/ang (1-7)/mas axis and NADPH oxidase expression. International Heart Journal 2018:59:1445-53.

79 Nakaoka H, Mogi M, Kan-no H, et al. Effect of olmesartan on glucose metabolism involving angiotensin converting enzyme 2. Immunol Endocr Metab Agents Med Chem 2018;17:105-14.

80 Varagic J, Ahmad S, VonCannon JL, et al. Predominance of AT(1) blockade over mas-mediated angiotensin-(1-7) mechanisms in the regulation of blood pressure and renin-angiotensin system in mRen2.Lewis rats. Am J Hypertens 2013;26:583-90.

81 Araújo AAde, Araújo LdeS, Medeiros CACXde, et al. Protective effect of angiotensin II receptor blocker against oxidative stress and inflammation in an oral mucositis experimental model. $J$ Oral Pathol Med 2018;47:972-84.

82 Zhang $\mathrm{YH}$, Hao QQ, Wang $\mathrm{XY}$, et al. Ace2 activity was increased in atherosclerotic plaque by losartan: possible relation to anti-atherosclerosis. J Renin Angiotensin Aldosterone Syst 2015;16:292-300.

83 Wu J, Chen T, Zhang Y. GW26-e0735 cardiac ace2/mas expression and cardiac remodeling in hypertensive rats. J Am Coll Cardiol 2015;66:C76.

84 Chen L, M ZC Y, et al. Alterations of urinary angiotensin converting enzyme and ACE2 before and after perindopril medication in patients with diabetic kidney disease. Diabetes/Metabolism Research and Reviews 2015;31:51-83.

85 Graus-Nunes F, Santos FdeO, Marinho TdeS, et al. Beneficial effects of losartan or telmisartan on the local hepatic reninangiotensin system to counter obesity in an experimental model. World J Hepatol 2019;11:359-69.

86 Tanno T, Tomita H, Narita I, et al. Olmesartan Inhibits Cardiac Hypertrophy in Mice Overexpressing Renin Independently of Blood Pressure: Its Beneficial Effects on ACE2/Ang(1-7)/Mas Axis and NADPH Oxidase Expression. J Cardiovasc Pharmacol 2016;67:503-9.

87 Ishibashi Y, Matsui T, Yamagishi S, et al. Olmesartan blocks advanced glycation end products-induced VCAM-1 gene expression in mesangial cells by restoring angiotensin-converting enzyme 2 level. Horm Metab Res 2014;46:379-83.

88 Wang W, Song A, Zeng Y, et al. Telmisartan protects chronic intermittent hypoxic mice via modulating cardiac renin-angiotensin system activity. BMC Cardiovasc Disord 2018;18:133.

89 Malek V, Sharma N, Sankrityayan H, et al. Concurrent neprilysin inhibition and renin-angiotensin system modulations prevented diabetic nephropathy. Life Sci 2019;221:159-67.

90 Varagic J, Ahmad S, Voncannon JL, et al. Nebivolol reduces cardiac angiotensin II, associated oxidative stress and fibrosis but not arterial pressure in salt-loaded spontaneously hypertensive rats. $J$ Hypertens 2012;30:1766-74

91 lizuka K, Kusunoki A, Machida T, et al. Angiotensin II reduces membranous angiotensin-converting enzyme 2 in pressurized human aortic endothelial cells. J Renin Angiotensin Aldosterone Syst 2009;10:210-5.

92 Onat E. Effects of rosuvastatin and amlodipine on reninangiotensin system of kidney in NOS inhibition and salt diet induced hypertension. Journal of Cellular Neuroscience and Oxidative Stress 2018;10:693-4.

93 Zhang L-H, Pang X-F, Bai F, et al. Preservation of glucagon-like peptide-1 level attenuates angiotensin II-induced tissue fibrosis by altering AT1/AT 2 receptor expression and angiotensinconverting enzyme 2 activity in rat heart. Cardiovasc Drugs Ther 2015;29:243-55.

94 Awwad ZM, El-Ganainy SO, EIMallah Al, et al. Assessment of Pregabalin-Induced cardiotoxicity in rats: mechanistic role of angiotensin 1-7. Cardiovasc Toxicol 2020;20:301-11.

95 Romaní-Pérez M, Outeiriño-Iglesias V, Moya CM, et al. Activation of the GLP-1 receptor by liraglutide increases ACE2 expression, reversing right ventricle hypertrophy, and improving the production of SP-A and SP-B in the lungs of type 1 diabetes rats. Endocrinology 2015;156:3559-69.

96 Riera M, Márquez E, Clotet S, et al. Effect of insulin on ACE2 activity and kidney function in the non-obese diabetic mouse. PLOS One 2014;9:e84683.

97 Márquez E, Riera M, Pascual J, et al. Albumin inhibits the insulinmediated ACE2 increase in cultured podocytes. Am J Physiol Renal Physiol 2014;306:F1327-34.

98 Shin $\mathrm{YH}$, Min JJ, Lee J-H, et al. The effect of fluvastatin on cardiac fibrosis and angiotensin-converting enzyme-2 expression in glucose-controlled diabetic rat hearts. Heart Vessels 2017;32:618-27.

99 Salem ES, Chodavarapu H, Morris M, et al. Insulin normalizes angiotensin converting enzyme 2 (ACE2) and attenuates albuminuria in type 1 diabetic Akita mice. Hypertension 2012;60. 
100 Salem ESH. Acute and chronic complications. Diabetes 2013;62:A588-621.

101 Salem ESB, Grobe N, Elased KM. Insulin treatment attenuates renal ADAM17 and ACE2 shedding in diabetic Akita mice. Am J Physiol Renal Physiol 2014;306:F629-39.

102 Blanco-Gozalo V, Blazquez-Medela A, Garcia-Sanchez O, et al. Diabetes - experimental models. Nephrology Dialysis Transplantation 2013;28:i374-84.

103 Min JJ, Shin B-S, Lee J-H, et al. Effects of pravastatin on type 1 diabetic rat heart with or without blood glycemic control. J Diabetes Res 2018;2018:1-9.

104 Gupta RC, Want GRS. Long-Term therapy with ivabradine increases ace-2 activity in left ventricular myocardium of dogs with chronic heart failure. Circulation Research 2012;111.

105 Weili Q, Cheng W, Fan Z, et al. GW25-e4430 ibuprofen attenuates cardiac fibrosis via restoring the imbalance of ACE and ACE2 in diabetic rat. J Am Coll Cardiol 2014;64:C62.

106 Qiao W, Wang C, Chen B, et al. Ibuprofen attenuates cardiac fibrosis in streptozotocin-induced diabetic rats. Cardiology 2015;131:97-106.

107 Bukowska A, Spiller L, Wolke C, et al. Protective regulation of the ACE2/ACE gene expression by estrogen in human atrial tissue from elderly men. Exp Biol Med 2017;242:1412-23.

108 Hermenegildo C, Mompeon A, Perez-Cremades D, et al. [OP.6D.01] ESTRADIOL INCREASES ENDOTHELIAL ANGIOTENSIN-(1-7) PRODUCTION THROUGH ESTROGEN RECEPTOR ALPHA. J Hypertens 2016;34:e75.

109 Mompeón A, Lázaro-Franco M, Bueno-Betí C, et al. Estradiol, acting through $\mathrm{ER} \alpha$, induces endothelial non-classic reninangiotensin system increasing angiotensin 1-7 production. Mol Cell Endocrinol 2016;422:1-8.

110 Shenoy V, Grobe JL, Qi Y, et al. 17Beta-Estradiol modulates local cardiac renin-angiotensin system to prevent cardiac remodeling in the DOCA-salt model of hypertension in rats. Peptides 2009;30:2309-15.

111 Wang H, Zhao ZJJ, et al. Estrogen replacement downregulates cardiac angiotensin II in an ace-independent manner in oophorectomized mREN2. Lewis rats. Circulation Research 2013;113.

112 Wang G, Zhang Q, Yuan W, et al. Sildenafil protects against myocardial ischemia-reperfusion injury following cardiac arrest in a porcine model: possible role of the renin-angiotensin system. Int $J$ Mol Sci 2015;16:27015-31.

113 Thanekar U, Gill RK, Dhakal S, et al. Abstract P2044: renoprotective effects of canagliflozin in $\mathrm{db} / \mathrm{db}$ diabetic mice. Hypertension $2019 ; 74$.

114 Li Y-H, Wang Q-X, Zhou J-W, et al. Effects of rosuvastatin on expression of angiotensin-converting enzyme 2 after vascular balloon injury in rats. J Geriatr Cardiol 2013;10:151-8.

115 Suski M, Gębska A, Olszanecki R, et al. Influence of atorvastatin on angiotensin I metabolism in resting and TNF- $\alpha$-activated rat vascular smooth muscle cells. J Renin Angiotensin Aldosterone Syst 2014;15:378-83.

116 Aguilar C, Ventura F, Rodríguez-Delfín L. [Atorvastatin induced increase in homologous angiotensin I converting enzyme (ACE2) mRNA is associated to decreased fibrosis and decreased left ventricular hypertrophy in a rat model of diabetic cardiomyopathy]. Rev Peru Med Exp Salud Publica 2011;28:264-72.

117 Jessup JA, Brosnihan KB, Gallagher PE, et al. Differential effect of low dose thiazides on the renin angiotensin system in genetically hypertensive and normotensive rats. J Am Soc Hypertens 2008;2:106-15.

118 Sánchez-Aguilar M, Ibarra-Lara L, Del Valle-Mondragón L, et al. Rosiglitazone, a Ligand to PPAR $\gamma$, Improves Blood Pressure and Vascular Function through Renin-Angiotensin System Regulation. PPAR Res 2019;2019:1-12.

119 Scroggin MPK. The PPAR-\{gamma\} agonist Rosiglitazone increases Angiotensin-Converting Enzyme 2 (ACE2) promoter activity in neurons. FASEB Journal 2012;26.

120 Zhang W, Li C, Liu B, et al. Pioglitazone upregulates hepatic angiotensin converting enzyme 2 expression in rats with steatohepatitis. Ann Hepatol 2013;12:892-900.

121 Aguilar MS, Aguilar-Navarro A, Ibarra-Lara L, et al. Ppar gamma stimulation by rosiglitazone decreases blood pressure and renal apoptosis in a rat hypertension model secondary to aortic coarctation. J Hypertens 2018;36:e43.

122 Chodavarapu H, Grobe N, Somineni HK, et al. Rosiglitazone Treatment of Type 2 Diabetic db/db Mice Attenuates Urinary Albumin and Angiotensin Converting Enzyme 2 Excretion. PLoS ONE 2013;8:e62833.

123 Ali RM, Al-Shorbagy MY, Helmy MW, et al. Role of Wnt4/ $\beta$ catenin, Ang II/TGF $\beta, A C E 2, N F-\kappa B$, and IL-18 in attenuating renal ischemia/reperfusion-induced injury in rats treated with Vit $D$ and pioglitazone. Eur J Pharmacol 2018;831:68-76.

124 Andersen LB, Przybyl L, Haase N, et al. Vitamin D depletion aggravates hypertension and target-organ damage. J Am Heart Assoc 2015;4:e001417.

125 da Silva Machado C, Aissa AF, Hernandes LC, et al. Vitamin D3 regulates genes involved with the renin-angiotensin-aldosterone system in hypertensive and normotensive rats. Toxicol Lett 2014;229:S231.

126 Lin M, Gao P, Zhao T, et al. Calcitriol regulates angiotensinconverting enzyme and angiotensin converting-enzyme 2 in diabetic kidney disease. Mol Biol Rep 2016;43:397-406.

127 Xu J, Yang J, Chen J, et al. Vitamin D alleviates lipopolysaccharide-induced acute lung injury via regulation of the renin-angiotensin system. Mol Med Rep 2017;16:7432-8.

128 Speth R, Carrera E J-BM, et al. Concentration-Dependent effects of zinc on angiotensin-converting enzyme-2 activity. FASEB Journal $2014 ; 28$. 